\title{
Privatisation and Performance of Electricity Distribution Companies in Nigeria
}

\author{
Adebayo O. Adedeji, \\ Department of Political Science and Public Administration \\ College of Management and Social Sciences, Redeemer's University, Ede. \\ E-mail: adedejia@run.edu.ng
}

Received: May 4, 2017 Accepted: July 26, 2017 Online published: September 1, 2017

doi:10.5296/jpag.v7i3.11168～URL: https://doi.org/10.5296/jpag.v7i3.11168

\begin{abstract}
Privatisation of public enterprises is a complex phenomenon as the process is affected by both endogenous and exogenous factors. Advocates of privatisation of public enterprises in Developing countries tend to have a linear perspective that it will result in efficiency and improved performance of these firms. However, several studies have shown that this is not always the outcome. This paper examined the privatisation and performance of Electricity Distribution Companies in Nigeria and concluded that the outcome was determined more by the form and nature of the government than by the process of privatisation. Therefore, there is a need for further research to identify factors that could enhance or inhibit the success of the privatisation process in Developing countries.
\end{abstract}

Keywords: Privatisation, Performance Measurement, Electricity, Public Enterprises

\section{Introduction}

Power is considered as one of the major impetus for development. A nation that cannot generate enough electricity to power its industries will remain at the doldrums of underdevelopment. Successive government in Nigeria over the years has been experimenting with various policy options on how to improve the power sector in the country. However, they failed to make the necessary investment in the power sector. Much of what obtains as observed by Nnaji (2011) are high energy losses (technical and non-technical), inadequate expertise, high operating cost (more than $80 \%$ goes into staff salaries and welfare). With this trend, it was difficult, if not impossible for the government under the fourth republic to make any significant change in the power sector. Analyst estimated that the Federal government will need on a yearly bases 70 billion naira to improve the generation and transmission capacity of the country. This kind of investment could not be sustained by the government. 
Hence the need for the involvement of the private sector in the development of the power sector in Nigeria. It was on this bases that privatisation was conceived.

Privatisation was seen by many as the main solution to all the challenges encountered in the power sector. Previous attempts at making the sector more efficient and effective had failed. A major reason attributed for this failure was that the attempts still gave government the majority stake in the sector. To remedy the situation, it was argued that total divestiture of government from public enterprises involved in the generation, transmission and distribution of electricity will lead to proper utilization of resources and better performance (ibid). The process of privatisation of the power sector began with the unbundling of National Electric Power Authority (NEPA) to Power Holding Company of Nigeria. The unbundling was to allow for a smooth transition from government monopoly to private entities. The Power Holding Company of Nigeria was later unbundled into Transmission Company of Nigeria (TCN), six generating companies and eleven distribution companies.

The aim of this further unbundling was to improve the performance of these public enterprises and fast track the process of getting electricity across to more Nigerians. In the area of performance, not all privatised public enterprises have met the expectation the citizens. Some of the factors adduced for this poor performance range from non-investment in necessary equipments and human resources to poor management. The assumption of technocrats and policy makers is that privatisation would ameliorate these issues and improve performance. However, available evidence has shown that this is not always the outcome. (Villalonga, 2000, Willner, 2001)

This paper seeks to evaluate the performance of Electricity Distribution Companies in Nigeria within the context of privatisation from inception till date. The aim is to ascertain if the privatisation of these distribution companies has led to better performance in terms of increase in electricity supply and customer satisfaction. This will be done using content analysis of secondary data obtained from newspaper reports, government publications and academic journals.

\section{Literature Review: the Philosophy of Privatisation}

The term privatisation connotes different meanings particularly when defined by those adopting it. Nwankwo and Richards (2001) observed that "the term privatisation is hardly amenable to categorical precise definition". This is because beyond giving it a meaning, a lot of people define it from the context of the purpose it is meant to serve. In other words, privatisation could be seen from the perspective of extending the activity of the private sector to provide public services or rolling back the sphere of the public sector often accused of inefficiency and poor performance in the delivery of public services. Notwithstanding, there are some basic characteristics of privatisation. Iheme (1997) defines privatisation as "any of a variety of measures adopted by government to expose a public enterprise to competition or to bring in private ownership or control or management into a public enterprise and accordingly to reduce the usual weight of public ownership or control or management". This definition basically focuses on public enterprise without considering that the services these agencies provide could also be privatised. For instance, in the telecommunication sector in Nigeria, the 
sector was deregulated (another element of privatisation) by licensing private companies to provide telecommunication services which used to be provided by government monopoly; NITEL. Thus, privatisation is not only about transferring ownership of public enterprises to private individuals, it could also be the transfer of delivery of public services to the private sector. In this context, Adams et al (1992) describe privatisation as an "array of actions designed to broaden the scope of private sector market activity or the assimilation by the public of efficiency-enhancing techniques generally employed by the private sector". In other words, the private sector is known for efficiency and effectiveness in the discharge of its responsibilities. Thus, to improve the efficiency of public enterprises and better service delivery, government should privatise them. This probably informs the decision of government to embark on the privatisation of its public entities. The assumption underlining this perspective is that once privatised, there is going to be an improvement in the performance of these public enterprises. However, this has not often been the case. Willner (2001) in the review of empirical evidence observed that the ownership structure of these corporations (public or private) makes little difference to efficiency.

The debate on privatisation and efficiency has been extensive and the conclusion reached devised. For instance, Martin and Parker (1997) stated that "on balance it seems that neither private nor public sector production is inherently or necessarily more efficient". Their statement was informed by the review of both empirical and theoretical studies on the effect of privatisation on efficiency. They observed that privatisation alone is not a sufficient variable to guarantee efficiency. Villalonga (2000) is of the view that privatisation is not the sole variable for achieving efficiency as there are other intervening variables that could make privatisation achieve efficiency in a firm. These intervening variables were often not considered in the study of privatisation and efficiency. Villalonga noted that there are political and organisational implications of privatisation and these variables to a large extent determine if privatisation will lead to efficiency in the firm. For example, the political implication of privatisation is the pursuit by government of goals other than efficiency. One of such goals is the pursuit of revenue to be generated from privatisation than the efficiency of the hitherto public entity. Similarly, organisational implications could be the inability of the new owners to turn-around the performance of the privatised firm due to certain unforeseen circumstances.

Other studies done on privatisation also acknowledge the limitations of privatisation in achieving efficiency. Odeh (2011) is his study of privatisation of public enterprises and productivity in Nigeria came to the conclusion that certain factors such as corruption and lack of transparency in the process was affecting the privatisation policy. Therefore, it is not enough to just embark on privatisation without taking in to consideration other factors that could stifle the desired benefits. In other words, government must put in place certain institutional framework that would allow the privatisation of these public enterprises yield the desired results. This observation by Odeh (2011) is in line with those of Nwankwo and Richards (2001), who evaluated privatisation in Sub-Saharan Africa. They argued that "the form of government determines the nature and scope of privatisation". Thus, if the government in power is one that exhibit quasi-military tendencies or is paternalistic in nature, 
the outcome of privatisation will be unsatisfactory. The reasons they adduce is the prevalence of absolute corruption, mismanagement and poverty level. These forms of government are often dictatorial and undemocratic thereby making them unresponsive and unaccountable to the citizens. Consequently, corruption will be rift in these countries. Similarly, since the citizens are already impoverished, there is a high tendency to resist the privatisation process as they (citizens) associate it with price increase. This observation by Nwankwo and Richards is further buttress by David hall et al (2005). They examined public resistance to privatisation in water and energy and observed that worldwide, there is a strong public resistance to privatisation. This is because of its inability to meet the expectations of the people and the perception that it negates the principle of equity (Birdsall and Nellis 2002). Most times, if not in all cases, there is a tendency for a sight adjustment in the price of the service been rendered to accommodate profit margin and operational cost. However, this sight increase may be a burden to the majority who cannot afford to pay for the increase and do not have alternative options of accessing such services.

The conclusion to be drawn from the above analysis is that privatisation may not improve the efficiency of these public corporation has argued by several empirical studies. These studies posit that there are other intervening variables which if not factored into the privatisation process, may not yield the desired outcome of efficiency.

\section{Privatisation of the Power Sector in Nigeria}

Historically, power generation in Nigeria started towards the end of the $19^{\text {th }}$ century. The first power plant was built in Marina, Lagos in 1898 (Awosope, 2014). Since then the sector grew to a single monopoly of National Electric Power Authority (NEPA) which was created on $1^{\text {st }}$ of April, 1972. However, the power sector under NEPA decayed to a deplorable state of epileptic power supply, over-billing and corrupt practices of its staff. Dikki (2014) gave a chronicle of the state of the power sector on return to civilian rule in 1999. He stated that:

- Of the 79 generation units in the country, only 19 units were operational. Average daily generation was $1,750 \mathrm{MW}$.

- $\quad$ No new electric power infrastructure was built between 1991 and 1999.

- $\quad$ The newest plant was completed in 1990 and the last transmission line built in 1987.

- An estimate 90 million people were without access to grid electricity.

This was the situation in the power sector when democratic rule was restored in the country in 1999. The administration of President Obasanjo embarked on a series of reforms to revamp the power sector. Part of the reform was the enactment of the Electric Power Sector Reform (EPSR) Act, 2005. The Act stipulated measures to be taken to address the rot in the power sector. The objectives of the Act according to Aminu and Peterside (2014) include "making electricity generation and supply available to consumers, making the sector investor friendly and dismantling NEPA's monopoly". These could be seen as the identified anomalies in the power sector. Furthermore, the Act provided for a holding company; Power Holding Company of Nigeria (PHCN) to oversee the transition from NEPA to eighteen successor 
companies of one transmission company (Transco), six generation companies (Gencos) and eleven distribution companies (Discos). The Act also provided for the establishment of the Nigeria Electricity Regulatory Commission (NERC), which according to Inugonam (2005) is saddled with the following responsibilities:

\section{Regulate tariffs and quality service}

2. Oversee the activities of the industry for efficiency

3. Institutional and enforcement of the regulatory regime.

4. Licensing of Generation, Distribution, Transmission and Trading companies that result from the unbundling of NEPA.

\section{Legislative authority to include special conditions in Licenses.}

6. Provision relating to public policy interest in relation to fuel supply, environmental laws, energy conservation, management of scarce resources, promotion of efficient energy, promotion of renewable energy and publication of reports and statistics.

7. Providing a legal bases with necessary enabling provisions for establishing, changing, enforcing and regulating technical rules, market rules and standards.

Similarly, the Federal government set targets in line with the measures listed in the Electricity Reform Act of 2005. According to the Road Map for Power Sector reform (2010), the Federal government estimated that with the completion of all the Independent Power Plants and refurbishment of the existing ones, power generation available for distribution should be 14,000 Megawatts by December, 2013.

The privatisation process began with the submission of bids by interested investors in the distribution and generation companies. These bids were evaluated and the preferred bidders were announced. Table 1 below is a list of the shortlisted bidders and firms that purchased the bid forms.

Table 1.

\begin{tabular}{|l|l|l|l|}
\hline & SHORTLISTED & FIRMS PURCHASING BID DOCUMENTS & PERCENTAGE \\
\hline HYDRO & 40 & 35 & $88 \%$ \\
\hline THERMAL & 87 & 56 & $64 \%$ \\
\hline DISTRIBUTION & 80 & 72 & $90 \%$ \\
\hline TOTAL & 207 & 163 & $79 \%$ \\
\hline
\end{tabular}

Source: Okonkwo 2015.

This process was followed up with technical evaluation of the bidders, financial opening and announcements of the preferred bidder and the completion and handing over of these companies on November 1, 2013. The table shows the amount paid for each the distribution companies: 
Table 2.

\begin{tabular}{|l|l|l|l|}
\hline $\begin{array}{l}\text { SUCCESSOR } \\
\text { COMPANY }\end{array}$ & BIDDER & $\begin{array}{l}\text { PURCHASE } \\
\text { (DOLLARS) }\end{array}$ & $\begin{array}{l}\text { PURCHASE PRICE } \\
\text { (NAIRA) }\end{array}$ \\
\hline ABUJA & KANN & $164,000,000$ & $25,799,000,000$ \\
\hline BENIN & VIGEO & $129,000,000$ & $20,215,000,000$ \\
\hline EKO & $\begin{array}{l}\text { WEST POWER AND } \\
\text { GAS }\end{array}$ & $135,000,000$ & $21,182,000,000$ \\
\hline ENUGU & INTERSTATE & $126,000,000$ & $19,803,000,000$ \\
\hline IBADAN & INTEGRATED & $169,000,000$ & $26,505,000,000$ \\
\hline IKEJA & NEDC & $131,000,000$ & $20,638,000,000$ \\
\hline JOS & AURA & $82,000,000$ & $12,852,000,000$ \\
\hline KADUNA* & NORTHWEST & $163,000,000$ & $25,612,000,000$ \\
\hline KANO & SAHELIAN & $137,000,000$ & $25,612,000,000$ \\
\hline PORT HARCOURT & 4POWER & $124,000,000$ & $21,438,000,000$ \\
\hline YOLA & INTEGRATED & $59,000,000$ & $19,506,000,000$ \\
\hline
\end{tabular}

*Kaduna was completed in 2014

Source: Okonkwo 2015.

These Distribution Companies (DISCOs) were to cover certain states in the country. Below is a list of the eleven Distribution Companies and their coverage states:

\section{Successor Disco States Covered / Franchise Areas}

Abuja Disco $\quad$ FCT, Niger, Nassarawa, Kogi

Benin Disco Edo, Delta, Ekiti, Ondo

Enugu Disco Imo, Anambra, Ebonyi, Abia, Enugu

Eko Diso Lagos State (Victoria Island, Lekki, Lagos Island, Apapa, Epe, Ikoyi, etc)

Port Harcourt Rivers, Bayelsa, Cross Rivers, Akwa Ibom

Disco

Ibadan Disco Oyo, Ogun, Osun, Kwara

Ikeja Disco Lagos State (Ikeja, Surulere, Ikorodu, etc)

Jos Disco Plateau, Bauchi, Benue, Gombe

Kano Disco Kano, Jigawa and Katsina

Kaduna Disco Kaduna, Sokoto, Kebbi and Zamfara

Yola Disco Adamawa, Borno, Taraba and Yobe

Source: Omonfoman, 2016. 


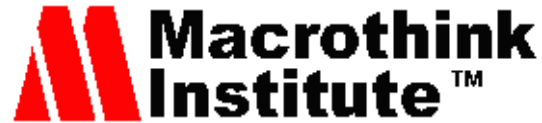

Journal of Public Administration and Governance ISSN 2161-7104 2017, Vol. 7, No. 3

The conclusion of the privatisation process in 2013 raised the expectations of citizens that the will be an improvement in the power sector, in the particular the services of the Distribution companies who are the frontline service providers. However, certain issues came up during and after the privatisation exercise.

Although, the privatisation process climaxed with the handing over of these companies to their new owners, the Federal government had to resolve certain labour issues. A major issue that arose during and after the privatisation process was how to pay compensation and severance to staffs of the defunct Power Holding Company of Nigeria. In a petition to President Buhari in 2015, the National Union of Electricity Employees (NUEE) alleged that about 50,000 employees of PHCN were still been owned benefits and another 5,000 yet to receive any entitlement two years after the privatisation of the companies. Similarly, the Union claimed that 50 billion naira meant to pay entitlements of ex-PHCN employees was lodged in a fixed deposit account (The Vanguard, 2015). However, these allegations were refuted by the Director-General, Bureau of Public Enterprise, (BPE), Mr. Benjamin Dikki that the proceeds from the sale of 17 successor companies of PHCN was used to pay the entitlements of the ex-employees of the defunct company (BusinessNews, 2015).

Apart from the labour issue that came after the privatisation process, other issues such as revenue generation by these distribution companies and availability of gas to power the thermal power came up. For instance, it is estimated that there will be a N809.8 billion electricity market revenue shortfall by December 2016 (The Punch Newspaper, 2016). The implication of this is that the distribution companies have been operating at a loss, thereby crippling their ability to provide efficient supply of electricity to its customers. Omofoman (2016) in his analysis of the electricity distribution companies, summarize the various challenges confronting them as follows:

* Grid energy insufficiency and instability;

*Network infrastructure challenges (overloaded transformers and feeders, obsolete equipment, limited network, lack of automation, etc);

* Tariff challenges and revenue shortfalls (non-cost reflective tariffs, low collection efficiency, etc);

* Metering challenges (huge metering gap, estimated billing, poor meter maintenance, etc);

* Operational challenges (long feeders, quality of workforce, large operational areas, etc);

* Energy theft;

* Funding challenges (absence of long term "patient" capital (equity/debt) to fund capex investment, high cost of borrowing, poor credit history of Discos, etc).

Omonfoman observed that these challenges were the issues the Federal government wanted the private sector to address when they privatised these distribution companies. However, the new owners are having problems resolving these challenges three year after the privatisation exercise has been completed. This has led to agitation in certain quarters for a review of the 
privatisation exercise. While this is not likely to occur, it goes to show that privatisation is not an end in itself but one of the means to an end. Similarly, the argument by Nwankwo and Richards (2001) on the forms of government and outcome of privatisation is evident in the Nigerian experience. For instance, the corruption perception index of Transparency International is measured on a scale of 0 (highly corrupt) to 100 (very clean). This means that the closer a country's score to 100 , the less corrupt that country is. However, the closer a country's score is to 0 , the more corrupt that country is. Therefore, for a country like Nigeria that ranked 143,139,144, 136 and 136 for the year 2011, 2012, 2013, 2014 and 2015 respectively shows that there was only a marginal improvement in the corruption perception index of the country. An indication that corruption is still pervasive in the public sector and it is within this context that the privatisation exercise was concluded. The deduction to be made here is that the public officials involved in the privatisation exercise will be more interested in the proceeds from the sale than in the capacity of the buyer/investor to improve the performance of these enterprises. This is because it is from the proceeds that these officials can perpetuate acts of embezzlement and misappropriation of public funds. Evidence of these acts was brought to light by Asaolu (2015) citing the Senate Committee investigating the privatisation of public enterprises in 2011. He observed that the privatisation exercise was; more or less a total mess brought about by corruption-inspired undervaluation of enterprises privatised, sale of the undervalued enterprises to cronies and political associates, assets stripping, clear breaches of due process, wilful refusal of regulating organs (the National Council on Privatisation (NCP) and Bureau of Public Enterprises (BPE) to adopt the guidelines of the Public Enterprises (Privatisation and Commercialisation) Act of 1999 which is the extant law and economic sabotage by the operators of the system.

That these distribution companies were sold to political associates could be seen in the privatisation exercise. For example, certain individuals who had held political positions in the past were named as either chairman or chief executive officer of the consortium that acquired these companies (Energy Mix Report, 2013, Leadership Newspaper, 2014). This raises concern of whether financial capability of these investors took precedence over their technical capacity to improve the efficiency of these distribution companies. The next section evaluates the performance of these distribution companies since their privatisation in 2013.

\section{Evaluation of the Performance of Electricity Distribution Companies in Nigeria}

One of the major concerns of scholars and practitioners in the field of Public Administration is performance measurement. This is because programmes and public institutions are created for specific purposes and it is pertinent to ascertain if they (public institutions and programmes) are fulfilling this purpose. As a result, performance measurement procedures were developed to ascertain the efficiency and effectiveness of these public institutions and programmes.

The United States General Accounting Office (1998) conceptualizes performance measurement as "the ongoing monitoring and reporting of program accomplishments, particularly progress towards pre-established goals". This view highlights the importance of measuring output or outcome in comparison to stated goals and objectives. Consequently, the 
operations of these public organisations are broken into detailed inputs (human, material and financial resources) required to generate certain outputs (products and services delivered), which will lead to a desired outcome (consequences of the products and services delivered). The programme under evaluation here is the privatisation of the Electricity Distribution Companies in Nigeria with the intention of making more effective and efficient in terms of service delivery. However, performance measurement is not an end in itself as Behn (2003) argues that "neither the act of measuring performance nor the resulting data accomplishes anything itself; only when someone uses these measures in some way do they accomplish something". Therefore, the intention of performance measurement is for citizens to hold their elected officials accountable for public programmes and for government to hold accountable public managers of public organisations and programmes (Osborne and Plastrik, 2000). While the intentions of performance measurement appear credible, there is the need to exercise caution when engaging in the process. Serrat (2010) argues that "what is important cannot always be measured and what can be measured is not always important". This is because performance measurement, particularly of public programmes and organisations, do not always exhibit a cause and effect relationship. There are other intervening variables that could have generated the manifested outcome or inhibiting the desired goals which were not taking into account during the performance evaluation exercise. Notwithstanding, it serves as a prism through which to ascertain the likely trajectory of a public programme.

The Electricity Distribution Companies (DISCO) are the front-end organisations in the electricity value chain. They serve as the interface between the citizens/customers and the power sector. Consequently, most evaluation of the performance of the DISCOs tends to have elements of customer satisfaction imbedded in them. For instance, Edwin Anyim (2016) assessed customers' satisfaction of DISCOs by examining the services provided. While the author used several parameters, a major highlight of the assessment was that most customers get estimated billing as against the installation and use of pre-paid meters. This gives room for customers to be billed for electricity they did not consume and creates dissatisfaction with the services of these DISCOs. Usman (2013) developed a model for assessing customers' satisfaction with the services provided by the then Abuja Electricity Distribution Zone. The model had four parameters which are as follows;

* The Product-Customization; Value Information; Scope; Accuracy of product quality; and guaranty.

* The Service-Attitude; Information Distribution; Response and feedback; Call center; Quality; Service manager.

* The Network-Safety; Reliability; Operability; System Accessibility; System Humanization

* Willingness to Pay-Accuracy of Bill; Accuracy of Tariff Payment Method; Payment Facilities; Inherited Bills.

Usman (2013) observed that:

"The consumers are not satisfied with the product-electricity- as supplied by the 
existing Abuja Disco in general and in particular, the business unit. This is occasioned by inadequate power supply, accentuated by the ever increasing supply-demand gap in the power industry.....

in most cases, the consumers do not regard the present condition with respect to electricity supply by the major stake holders as meeting consumers expectation. The extent of compliance to service standard is inadequate, while the technical competence as shown by the indexes of professionalism and continuity of service is also defective".

The above statement is a description of the performance trend noticeable across the various DISCOs in Nigeria. A report by the Independent Energy Watch Initiative (2016) ranked each of the DISCOs according to certain parameters highlighted in the table 3 below:

Table 3.

\begin{tabular}{|c|c|c|c|c|c|c|c|}
\hline $\begin{array}{c}\text { Distribution } \\
\text { Company } \\
\text { (DISCO) }\end{array}$ & $\begin{array}{l}\text { Responsiveness } \\
\text { (customer } \\
\text { service) }\end{array}$ & $\begin{array}{l}\text { Value } \\
\text { for } \\
\text { Money }\end{array}$ & $\begin{array}{c}\text { Quality of } \\
\text { Power } \\
\text { (electricity) }\end{array}$ & $\begin{array}{c}\text { Hours of } \\
\text { Availability } \\
\text { of } \\
\text { Electricity }\end{array}$ & $\begin{array}{c}\text { Customer } \\
\text { Communication } \\
\text { and } \\
\text { Engagement }\end{array}$ & $\begin{array}{c}\text { Electricity } \\
\text { Supply } \\
\text { Infrastructure }\end{array}$ & Overall \\
\hline Abuja & $7^{\text {th }}$ & $7^{\text {th }}$ & $3^{\text {rd }}$ & $4^{\text {th }}$ & $7^{\text {th }}$ & $6^{\text {th }}$ & $6^{\text {th }}$ \\
\hline Benin & $11^{\text {th }}$ & $10^{\text {th }}$ & $11^{\text {th }}$ & $10^{\text {th }}$ & $10^{\text {th }}$ & $10^{\text {th }}$ & $11^{\text {th }}$ \\
\hline Enugu & $6^{\text {th }}$ & $3^{\text {rd }}$ & $8^{\text {th }}$ & $5^{\text {th }}$ & $2^{\text {nd }}$ & $11^{\text {th }}$ & $5^{\text {th }}$ \\
\hline Eko & $10^{\text {th }}$ & $11^{\text {th }}$ & $9^{\text {th }}$ & $11^{\text {th }}$ & $11^{\text {th }}$ & $5^{\text {th }}$ & $10^{\text {th }}$ \\
\hline Ibadan & $8^{\text {th }}$ & $8^{\text {th }}$ & $10^{\text {th }}$ & $8^{\text {th }}$ & $9^{\text {th }}$ & $3^{\text {rd }}$ & $9^{\text {th }}$ \\
\hline Ikeja & $9^{\text {th }}$ & $9^{\text {th }}$ & $7^{\text {th }}$ & $6^{\text {th }}$ & $8^{\text {th }}$ & $4^{\text {th }}$ & $8^{\text {th }}$ \\
\hline Jos & $3^{\text {rd }}$ & $2^{\text {nd }}$ & $1^{\text {st }}$ & $1^{\text {st }}$ & $3^{\text {rd }}$ & $7^{\text {th }}$ & $1^{\text {st }}$ \\
\hline Kaduna & $4^{\text {th }}$ & $4^{\text {th }}$ & $4^{\text {th }}$ & $7^{\text {th }}$ & $1^{\text {st }}$ & $2^{\text {nd }}$ & $4^{\text {th }}$ \\
\hline Kano & $1^{\text {st }}$ & $5^{\text {th }}$ & $2^{\text {nd }}$ & $3^{\text {rd }}$ & $5^{\text {th }}$ & $1^{\text {st }}$ & $3^{\text {rd }}$ \\
\hline Port Harcourt & $5^{\text {th }}$ & $6^{\text {th }}$ & $6^{\text {th }}$ & $9^{\text {th }}$ & $6^{\text {th }}$ & $9^{\text {th }}$ & $7^{\text {th }}$ \\
\hline Yola & $2^{\text {nd }}$ & $1^{\text {st }}$ & $5^{\text {th }}$ & $2^{\text {nd }}$ & $4^{\text {th }}$ & $8^{\text {th }}$ & $2^{\text {nd }}$ \\
\hline
\end{tabular}

From the above table, none of the DISCOs performed above expectation in all the parameters used. The Jos DISCO was rated higher than others while the Benin DISCOs was rated the lowest in all the parameters. This survey is an indication that the expectations of the customers have not fully been met by the DISCOs. Similarly, reports cited in print and online media publications show a general level of dissatisfaction among customers of these Distribution Companies (The Authority Online, 2016 ). While customers view the performance of Distribution companies as low, the management of these Distribution Companies identify low revenue as the major factor hindering their performance. According to Business News (2014) the Distribution Companies were performing below average due to huge revenue leakages. The Investors that bought over these companies allege that they were not given adequate information on actual revenue losses incurred by them. Consequently, they (investors) had to contend with paying for power consumption without commensurate returns from consumers. In other words, the Distribution companies have to pay for power supplied by the Transmission Company to them from the proceeds it generates from consumers. However, the revenue generated from customers is far below the amount it needs 
to pay the Transmission Company. This has resulted in huge revenue losses by the Distribution Companies. It is projected that by January 2017, the revenue loss will amount to 809.8 billion naira (The Nation Newspaper, 2016). This revenue loss could affect the long term performance of these DISCOs as funds needed to upgrade electricity assets and service loan obligations to domestic commercial banks will be lacking. This creates a paradox as funds needed to improve the performance of these companies is lacking and customers may be unwilling to pay more for services they have not received. Omonfoman (2016) observed that "without funding or improving the revenue profile of DISCOs, there is a certainty that these operational challenges would continue to subsist". The solution according to him lies in the implementation of cost reflective tariff, capitalisation of DISCOs, access to long term debt financing etc. These measures are clearly going to be facilitated by the government through enactment appropriate policy incentives and approval of long term financing to DISCOs.

\section{Conclusion and Recommendation}

There is the need for a robust debate on the factors sufficient to make privatisation a success in developing countries. The argument that privatisation will enhance efficiency of public enterprises is one sided and tends to view it as an end in itself. The literature has shown that there are other intervening variables that can make or mar the goals of privatisation. This paper has identified the form and nature of government has one of the critical variables determining the success or failure of privatisation programme. A peripheral analysis of the privatisation of Electricity Distribution Companies may indicate a desire by the government for operational efficiency of these public enterprises. However, this paper has shown that the government was more interested in selling off these national assets. The regulatory framework put in place is weak and not pro-active. The National Electricity Regulatory Commission had fined these companies for poor performance in terms of better customer service. However, these companies have hinged their poor performance on factors exogenous to them. Therefore, without the resolution of these factors by the government, there is little they can do to improve their operational performance.

The conclusion of this paper is that a determining variable in the privatisation programme is the form and nature of government implementing it. Excluding the pre and post government activities in the privatisation programme will limit the ability of the exercise to achieve operational efficiency of public enterprises.

\section{References}

Adam, A., Cavendish, W., \& Mistry, P.S. (1992). Adjusting Privatisation, Case Studies from Developing Countries, London: James Currey.

Asaolu, T. (2015). Privatisation in Nigeria: Regulation, Deregulation, Corruption and the Way Forward. Available Online: www.thenationaonlineng.net/privatisation-in-nigeria-regualation-corruption-and-the-way-for ward.

Amina, I., \& Peterside, Z. B. (2014). The Impact of Privatisation of Power Sector in Nigeria: 
A Political Economy Approach. Mediterranean Journal of Social Sciences, 5(26), 111-118.

Awosope, C. A. (2014). Nigeria Electricity Industry: Issues, Challenges and Solutions. Covenant University $38^{\text {th }}$ Public Lecture Series, 3(2).

Behn, R. D. (2003). Why Measure Performance? Different Purposes Require Different Measures. Public Administration Review, 63(5), 586-606.

Birdsall, N., \& Nellis, J. (2002). Winners and Losers: Assessing the Distributional Impact of Privatisation. Center for Gobal Development Working Paper No.6, Washington DC: Center for Global Development.

BusinessNews. (2014). Power Distribution Firms blame poor performance on losses. Available online: http://businessnews.com.ng/2014/07/30/power-distribution-firms-blame-poor-performance-lo sses/

BusinessNews (2015). Workers' Compensation gulped PHCN sales proceeds. Available Online:

http://businessnews.com.ng/2015/04/02/workers-compensation-gulped-phcn-sales-proceeds-b pe/

Dikki, B. E. (2014). Update-Privatisation Issues. Available online: http://www.power.gov.ng/National\%20Council\%20on\%20Power/UPDATE\%200N\%20\%20P RIVATISATION\%20ISSUES.pdf

Edwin Anyim, E. A. (2016). The Challenges of Customer's Satisfaction In Electricity Distribution Companies in Nigeria. Arabian Journal of Business and Management Review, $3(12)$.

Energy Mix Report. (2013). Privatized Power Assets: Who are The New Owners? Available Online: www.energymixreport.com/privatized-power-assets-who-are-the-new-owners/

Hall, D., Lobina, E., \& de la Motte, R. (2005). Public Resistance to Privatisation in Water and Energy. Development in Practice, 15(314), 286-301.

Iheme. (1997). The Incubus: The Story of Public Enterprises in Nigeria. Abuja: The Helmsman Associates.

Independent Energy Watch Initiative. (2016). Electricity Distribution Company Mid-Year Ranking. Available online: http://iwin.org.ng/index.php/news/local/item/3637-electricity-distribution-company-mid-year -ranking.

Inugonam, T. (2009). Electricity Demand Challenges in Nigeria. PHCN News. January-August, 2009.

Leadership Online. (2014). Faces Behind Privatised Electricity Industry (2). Available online: http://leadership.ng/features/359169/faces-behind-privatised-electricity-industry-2 
Martin, S., \& Parker, D. (1997). The Impact of Privatisation: Ownership and Corporate performance in the UK, London:Routledge

Nnaji, B. (2011). Power Sector Outlook in Nigeria: Government Renewed Priorities. Available online:sec.gov.ng/files/Prof\%20Nnaji\%20Presentation.pdf.

Nwankwo, S., \& Richards, D. C. (2001). Privatisation: The Myth of Free Market Orthodoxy in Sub-Saharan Africa. International Journal of Public Sector Management, 14(2), 165-179.

Odeh, A. M. (2011). Privatisation of Public Enterprises and Productivity: Nigeria's Dilemma. Journal of Emerging Trends in Economic and Management Sciences (JETEMS), 2(6), 490-496.

Okonkwo, C. (2015). Nigeria's Power Privatisation Process: Learning Curves. CPCS.

Omonfoman, O. (2016). Electricity Distribution Companies: The Challenges and Way Forward. Available online: http://opinion.premiumtimesng.com/2016/01/04/electricity-distribution-companies-the-challe nges-and-way-forward-by-odion-omonfoman/

Osborne, D., \& Plastrik, (2000). The Reinventor's Fieldbook: Tools for Transforming Your Government, San Francisco, CA: Jossey-Boss.

Roadmap for Power Sector: www.nigeriapowersectorreform.org.

Serrat, O. (2010). The Perils of Performance Measurement. Washington, DC: Asian Development Bank.

The Authority Online. (2016). NERC Carpets Discos, Gencos for Poor Performance in 2015. Available online: www.authorityngr.com/2016/03/NERC-carpet-Discos-Gencos-for-poor-performance-in-2015/

The Nation Newspaper. (2016). Power Sector revenue loss may hit N809b. Available online: http://thenationonlineng.net/power-sector-revenue-loss-may-hit-n809b/

The NewsNigeria. (2016). Power Companies Give Reasons for Poor Performance. Available Online:

www.thenewsnigeria.com.ng/2016/01/power-companies-give-reasons-for-poor-performancel

The Punch Newspaper. (2016). FG yet to fulfil promises to DISCOs. Available online: www.punchng.com/fg-yet-fulfill-promises-discos-aned/

The Punch Newspaper online. (2016). Blackout: Experts, Power Firms differ on Privatisation review.

Available

online:

www.punchng.com/blackout-experts-power-firms-differ-privatisation-review/

The Vanguard online. (2015). Labour Threatens Action Over Unresolved Power Issues. Available online: www.vanguardngr.com/2015/11/labour-threatens-action-over-unresolved-power--issues/

Thisday Online (2016). Ending Discos Unruly Conduct. Available online: 


\section{Macrothink}

Journal of Public Administration and Governance ISSN 2161-7104 2017, Vol. 7, No. 3

www.thisdaylive.com/index.php/2016/08/16/ending-ending-discos-unruly-conduct.

United States General Accounting Office. (1998). Performance Measurement and Evaluation: Definitions and Relationship. Available online: http://www.gao.gov/special.pubs/gg98026.pdf

Usman, A. (2013). Determinants of Electricity Consumers Satisfaction in Selected Electricity Distribution Zones in Nigeria: Implications for Regulatory Activities. Journal of Asian Business Strategy, 3(6), 103-124.

Villalonga, B. (2000). Privatisation and Efficiency: Differentiating Ownership Effects from Political, Organisational and Dynamic effects. Journal of Economic Behaviour and Management, 42, 43-74.

Willner, J. (2001). Ownership, Efficiency and Political Interference. European Journal of Political Economy, 17(4), 723-748.

\section{Copyright Disclaimer}

Copyright for this article is retained by the author(s), with first publication rights granted to the journal.

This is an open-access article distributed under the terms and conditions of the Creative Commons Attribution license (http://creativecommons.org/licenses/by/4.0/). 